\title{
Breast metastases of gastric signet-ring cell carcinoma: a report of two cases and review of the literature
}

This article was published in the following Dove Press journal:

OncoTargets and Therapy

29 December 2014

Number of times this article has been viewed

\author{
Asumi lesato' \\ Takaaki Oba' \\ Mayu Ono' \\ Toru Hanamura' \\ Takayuki Watanabe' \\ Tokiko Ito' \\ Toshiharu Kanai' \\ Kazuma Maeno' \\ Katsuhiko Ishizaka ${ }^{2}$ \\ Hiroyuki Kitabatake ${ }^{3}$ \\ Daisuke Takeuchi ${ }^{4}$ \\ Akira Suzuki ${ }^{4}$ \\ Jun Nakayama ${ }^{5}$ \\ Ken-ichi Ito' \\ 'Division of Breast and Endocrine \\ Surgery, Department of Surgery, \\ Shinshu University School of Medicine, \\ Matsumoto, ${ }^{2}$ Department of Surgery, \\ liyama Red Cross Hospital, liyama, \\ ${ }^{3}$ Department of Gastroenterology, \\ liyama Red Cross Hospital, liyama, \\ ${ }^{4}$ Department of Gastrointestinal \\ Surgery, Shinshu University School of \\ Medicine, Matsumoto, ${ }^{5}$ Department \\ of Molecular Pathology, Shinshu \\ University Graduate School of \\ Medicine, Matsumoto, Nagano, Japan
}

Correspondence: Ken-ichi Ito Division of Breast and Endocrine Surgery, Department of Surgery, Shinshu University School of Medicine, 3-I-I Asahi, Matsumoto, Nagano 390-862I, Japan

$\mathrm{Tel}+8 \mathrm{I} 263372657$

Fax +8I 26337272 I

Email kenito@shinshu-u.ac.jp
Abstract: It is occasionally difficult to diagnose breast metastasis of gastric carcinoma because of its rarity. However, to appropriately treat patients with breast tumors without delay, it is important to distinguish metastatic cancer from primary breast cancer. We report two cases of breast metastasis of gastric carcinoma and review the literature. The first case was a 41-year-old female diagnosed with bilateral pelvic tumors who visited the outpatient clinic because of pain and enlargement of both breasts. Ultrasonography showed diffuse hypoechoic lesions, which were enhanced on gadolinium-enhanced magnetic resonance imaging in the bilateral mammary gland. Core needle biopsy of the right breast revealed signet-ring cells, which were also identified in the resected bilateral pelvic tumors. Subsequent upper gastrointestinal endoscopy revealed signet-ring cell carcinoma in the stomach, and the bilateral breast lesions were diagnosed as metastases of gastric carcinoma. The second case was a 34-year-old female diagnosed with cervical metastasis of signet-ring cell carcinoma who was referred to the breast cancer clinic because of a nodule in the left breast detected by computed tomography. Ultrasonography showed a hypoechoic nodule that was enhanced on gadolinium-enhanced magnetic resonance imaging. Because the pathologic findings for the left breast nodule were quite similar to those of gastric cancer and its cervical metastasis, the breast nodule was diagnosed as a metastasis of gastric carcinoma. When a breast tumor is suspected to have metastasized from a primary tumor in another organ, particularly if signet-ring cells are found, the possibility that gastric cancer is present should be considered.

Keywords: gastric carcinoma, breast metastasis, signet-ring cell carcinoma, gastric cancer, breast cancer

\section{Introduction}

Breast metastases from extramammary neoplasms are rare, ${ }^{1}$ and only 41 cases of metastases to the breast from gastric cancer have been reported. Therefore, the clinicopathologic features of breast metastases from gastric cancer have not been fully described. We report two cases of metastatic gastric signet-ring cell carcinoma of the breast and review the literature.

\section{Case I}

A 41-year-old female was admitted to our department of gynecology with metrorrhagia. Pelvic ultrasonography revealed bilateral pelvic tumors and a myoma of the uterus. To make a definitive diagnosis of the bilateral pelvic tumors, total hysterectomy with bilateral salpingo-oophorectomy was planned. 
At the same time, she was referred to the breast cancer outpatient clinic for bilateral breast pain and swelling. She had no particularly relevant past history or family history. Physical examination revealed diffuse induration with uneven surface and tenderness in the bilateral breast. Although the density of the bilateral breast was high, mass or calcification was not detected by mammography. Ultrasonography showed diffuse mottled hypoechoic lesions in the bilateral mammary glands. Magnetic resonance imaging (MRI) of the right breast showed an extensive enhanced area in the mammary gland (Figure 1A) with edema of retromammary adipose tissue and skin in the delayed phase (Figure 1B). Axillary lymph node swelling was also detected by MRI. Core needle biopsy of the right breast revealed diffuse infiltration of signet-ring cells in the mammary gland (Figure 2A), and intracytoplasmic lumens also were seen (Figure 2B).

Because the pathologic examinations of the resected pelvic tumors also revealed signet-ring cells in the bilateral ovaries, suggesting that the tumor metastasized from another site, upper gastrointestinal endoscopy was performed to identify the primary site. Upper gastrointestinal endoscopy showed an ulcerative lesion similar to a Borrmann type 4 tumor in the lower part of the stomach. Pathologic examination of a biopsy specimen from the stomach revealed infiltration of signet-ring cells similar to the infiltration observed in the breasts and ovaries. Immunohistochemical analyses showed positive staining for $\mathrm{p} 53$ in the stomach and breast lesions. In addition, staining of MUC5AC and HIK1083, which are specific markers of gastric gland mucin, was also positive in the stomach and breast lesions. Based on these findings, we diagnosed the breast lesions as metastases from the gastric carcinoma.

Combination therapy of S-1 and cisplatin was administered after the diagnosis, and the metastatic tumors in the breasts became impalpable after two cycles of therapy. Further, MRI of the right breast showed neither enhancement nor edematous changes. Although there was no recurrence of breast lesions, the patient died from

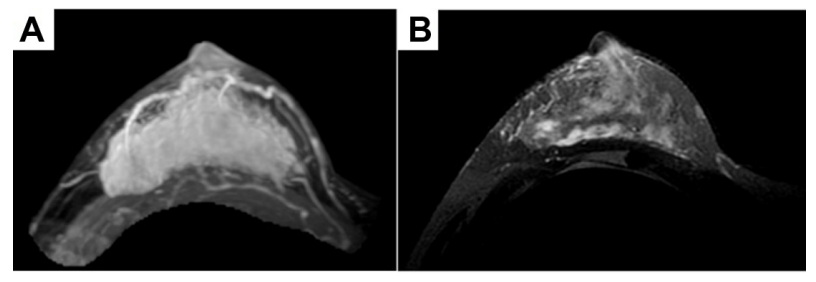

Figure I Magnetic resonance imaging findings of the right breast in case I. Notes: Three-dimensional maximum intensity projection of a magnetic resonance image shows a wide enhanced area in the delayed phase (A), and a T2-weighted image shows edematous changes in the retromammary fat tissue and skin of the same area (B).

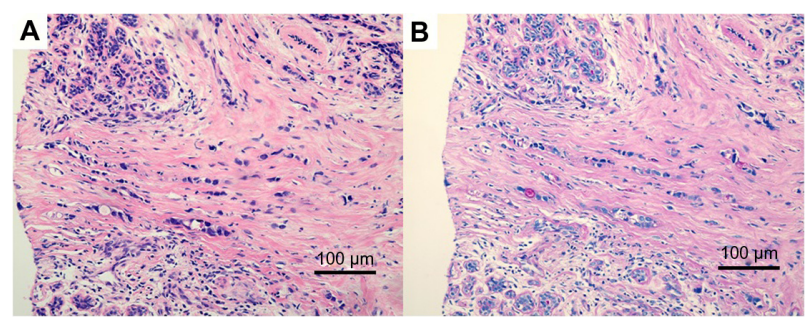

Figure 2 Pathologic findings of the breast lesion in case $\mathrm{I}$.

Notes: Pathologic examination of the right breast in case I reveals diffuse and trabecular infiltration of signet-ring cells (A, hematoxylin and eosin staining) and intracytoplasmic lumens are seen (B, periodic acid-Schiff staining).

meningeal dissemination of gastric cancer approximately 10 months later.

\section{Case 2}

A cervical polyp was detected in a 34-year-old female during health screening. Biopsy of the cervical polyp revealed poorly differentiated adenocarcinoma with signet-ring cells. To explore the primary site, a computed tomography scan was performed, which revealed a small nodule enhanced by contrast material in the left mammary gland. She was referred to our department for further examination of the breast.

Physical examination revealed a $1 \mathrm{~cm}$ diameter nodule in the upper outer quadrant of the left breast. Mammography showed no abnormal findings. Ultrasonography showed a hypoechoic $1 \mathrm{~cm}$ diameter nodule with irregular shape in the upper outer quadrant of the left breast. MRI of the left breast showed a $1 \mathrm{~cm}$ diameter nodule that was enhanced by contrast material in the early phase, but the enhancement was washed out in the delayed phase (Figure 3). The axillary lymph node was not swollen. Core needle biopsy of the

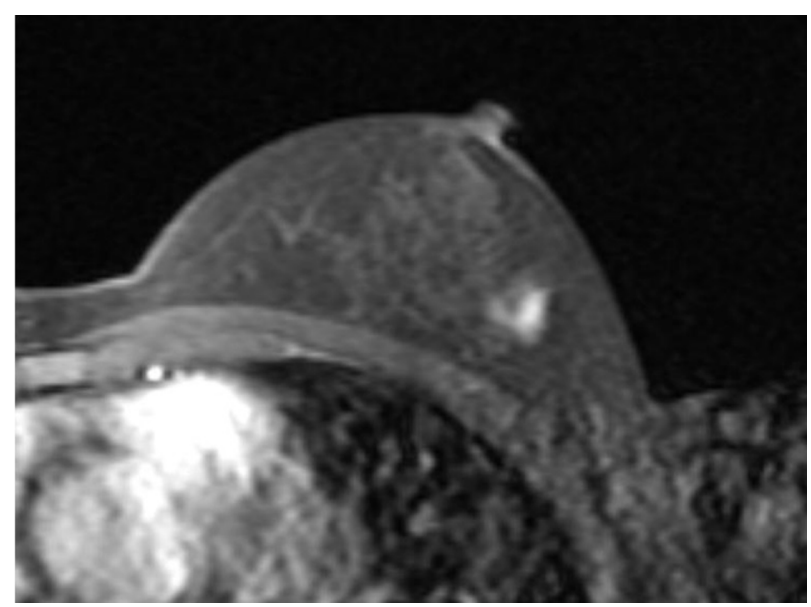

Figure 3 Magnetic resonance imaging findings of the left breast in case 2 .

Notes: Maximum intensity projection of magnetic resonance imaging of the left breast in case 2 shows a $\mathrm{I} \mathrm{cm}$ diameter nodule that is enhanced in the early phase. 
left breast tumor revealed diffuse infiltration of signet-ring cells in the mammary gland (Figure 4A), which were estrogen receptor-negative, progesterone receptor-negative, and human epidermal growth factor receptor type 2-negative. The pathologic findings of the breast and cervical lesions suggested that there might be a primary lesion in the stomach. Subsequent upper gastrointestinal endoscopy showed an ulcerative lesion with a Borrmann type 3 appearance on the wall of the middle gastric body. Biopsy of the gastric lesion revealed infiltration of signet-ring cells (Figure 4B). Positive staining of specific markers of gastric gland mucin (HIK1083, GCDFP15, and MUC6) was observed in the breast (Figure 4C) and gastric lesions (Figure 4D). Based on these findings, we diagnosed the breast lesions as metastases from the gastric carcinoma.

The patient received combination chemotherapy of S-1 and cisplatin. Her condition has remained stable without progression of the primary tumor in the stomach or of the metastatic tumor in the breast for 7 months.

\section{Discussion}

In contrast with breast carcinomas, metastatic tumors of the breast from extramammary malignancies are rare, ${ }^{1}$ and these tumors account for approximately $0.3 \%-2.7 \%$ of all malignant mammary tumors. ${ }^{1,2}$ Melanomas and lymphomas are the most common sources of breast metastases, followed by carcinomas of the lung, ovary, kidney, stomach, oropharynx, and carcinoid. ${ }^{3}$

With regard to breast metastases from gastric carcinomas, only 41 cases have been reported in the English literature (Table 1). ${ }^{2-38}$ All except one patient were female,

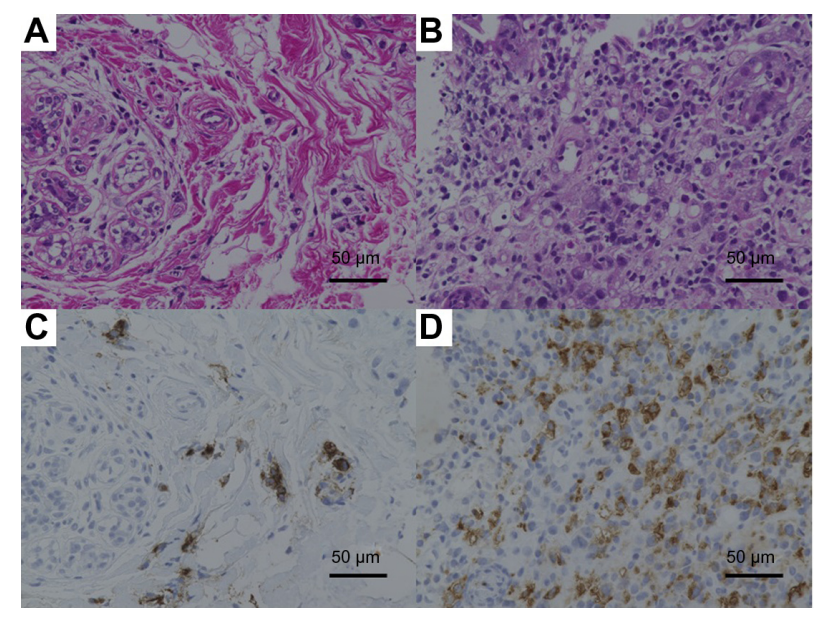

Figure 4 Pathologic findings of the breast and gastric lesion in case 2.

Notes: Pathologic examination of the left breast $(\mathbf{A})$ and gastric lesions $(\mathbf{B})$ in case 2 reveals infiltration of signet-ring cells (hematoxylin and eosin staining). Positive staining of HIK 1083 was observed in the breast (C) and gastric (D) lesions. and their ages ranged from 22 to 70 years (mean 45.5 years; median 46 years). Because the median age at diagnosis for breast cancer is 61 years in the USA and 58.3 years in Japan, ${ }^{39,40}$ metastatic breast cancers from gastric carcinoma tend to occur at ages younger than those for primary breast carcinomas. Histologically, approximately $66 \%$ of cases of breast metastases have shown signet-ring cell carcinoma, a type that accounts for approximately $10 \%$ of gastric cancers. ${ }^{41}$ In previous reports, it has been speculated that increased blood supply to the breast and hormonal factors associated with adhesion and growth of carcinoma cells may contribute to the higher incidence of breast metastases from gastric cancer in premenopausal women. ${ }^{32,35}$ In addition, because signet-ring cell carcinomas of the stomach are often seen among younger women, ${ }^{2,41}$ the incidence of metastasis of signet-ring cell carcinoma might be higher in the breasts of premenopausal women.

The clinical manifestations of gastric cancer breast metastases reported in the literature have not been consistent. In 41 previously reported cases, 19 cases $(46.3 \%)$ were found with palpable nodules, and ten cases (24.4\%), nine of which were signet-ring cell carcinomas, showed inflammatory changes. Chang et al reported that the incidence of inflammatory changes in breast metastasis from gastric carcinoma was at least four times higher than that in primary breast cancer, which has been reported to be $1 \%-5 \%{ }^{42}$

Interestingly, more than half of the breast metastases from the stomach have occurred in the left side. Lee et al reported that this laterality may suggest the presence of a lymphatic pathway or a higher incidence of invasion to the breast from the stomach via the left supraclavicular lymph node. ${ }^{1}$ However, more studies and observations are needed to elucidate the basis for this phenomenon.

Considering diagnostic imaging that has been performed, eleven of 41 cases had mammography, and well circumscribed nodules were detected in two, skin thickening in four, and no abnormal findings in five. ${ }^{32,33}$ In contrast, in ten cases that had ultrasonography, irregularly shaped hypoechoic nodules were found in five cases, diffuse hypoechoic lesion in two cases, skin thickening in three cases, and no abnormal findings in two cases. ${ }^{3}$ Thus, because there are no specific findings for metastatic breast cancer, it is considered difficult to diagnose metastatic breast cancer by diagnostic imaging findings alone.

Although the time from diagnosis of gastric cancer to that of breast metastasis has been reported to vary from zero to 72 months, approximately $40 \%$ of breast metastases were 
Table I Forty-one cases of breast metastasis from gastric cancer reported in the literature*

\begin{tabular}{|c|c|c|c|c|c|}
\hline Author & Sex & $\begin{array}{l}\text { Age } \\
\text { (years) }\end{array}$ & $\begin{array}{l}\text { Borrmann's } \\
\text { classification** }\end{array}$ & Histologic type ${ }^{* * * *}$ & $\begin{array}{l}\text { Clinical presentation } \\
\text { of breast lesion }\end{array}$ \\
\hline Reitmann ${ }^{4}$ & $\mathrm{~F}$ & 33 & - & Scirrhous carcinoma & - \\
\hline Kreibich $^{5}$ & $\mathrm{~F}$ & 65 & - & Scirrhous carcinoma & - \\
\hline Mourier et $\mathrm{al}^{6}$ & $\mathrm{~F}$ & 31 & - & Mucinous carcinoma & - \\
\hline Stahr ${ }^{7}$ & $M$ & 46 & - & Anaplastic carcinoma & - \\
\hline Dawson $^{8}$ & $\mathrm{~F}$ & 25 & - & Mucinous carcinoma & - \\
\hline Abrams et $\mathrm{al}^{9}$ & $\mathrm{~F}$ & - & - & - & - \\
\hline Sandison ${ }^{10}$ & $\mathrm{~F}$ & 56 & - & Signet-ring cell carcinoma & - \\
\hline Nance et al" & $\mathrm{F}$ & 59 & - & - & Inflammatory***** \\
\hline Hajdu et al' ${ }^{12}$ & $\mathrm{~F}$ & - & - & Adenocarcinoma & - \\
\hline Schmutzer et $\mathrm{al}^{13}$ & $\mathrm{~F}$ & 22 & 4 & Poorly differentiated adenocarcinoma & Nodules \\
\hline Silverman et $\mathrm{al}^{1 / 4}$ & $\mathrm{~F}$ & - & - & Mucin-producing carcinoma & - \\
\hline Toombs et $\mathrm{al}^{15}$ & $\mathrm{~F}$ & - & - & - & - \\
\hline Satake et $\mathrm{al}^{16}$ & $\mathrm{~F}$ & 39 & - & Signet-ring cell carcinoma & Nodule \\
\hline Togo et a $\left.\right|^{17}$ & $\mathrm{~F}$ & 70 & - & Signet-ring cell carcinoma & Nodule \\
\hline Nielsen et $\mathrm{al}^{18}$ & $\mathrm{~F}$ & 59 & - & Mucinous carcinoma & Nodules \\
\hline Champault et al ${ }^{19}$ & $\mathrm{~F}$ & 65 & - & Adenocarcinoma & Nodule \\
\hline Kasuga et $\mathrm{al}^{20}$ & $\mathrm{~F}$ & 48 & 3 & Signet-ring cell carcinoma & Nodules \\
\hline Tachibana et $\mathrm{a}^{21}$ & $\mathrm{~F}$ & 46 & - & Signet-ring cell carcinoma & - \\
\hline Alexander et $\mathrm{a}^{22}$ & $\mathrm{~F}$ & 28 & - & Carcinoma with mucinous differentiation & Nodules \\
\hline Hamby et $\mathrm{a}^{23}$ & $\mathrm{~F}$ & 31 & 4 & Signet-ring cell carcinoma & Nodule \\
\hline Mishina et $\mathrm{al}^{24}$ & $\mathrm{~F}$ & 36 & - & Signet-ring cell carcinoma & - \\
\hline Cavazzini et $\mathrm{al}^{25}$ & $\mathrm{~F}$ & 50 & - & Signet-ring cell carcinoma & Inflammatory**** \\
\hline Domanski ${ }^{26}$ & $\mathrm{~F}$ & 48 & - & Signet-ring cell carcinoma & Nodule \\
\hline de la Cruz Mera et al ${ }^{27}$ & $\mathrm{~F}$ & 61 & - & Signet-ring cell carcinoma & Nodule \\
\hline Briest et $\mathrm{a}^{28}$ & $\mathrm{~F}$ & 46 & 4 & Signet-ring cell carcinoma & Inflammatory**** \\
\hline Kudo et $\mathrm{al}^{29}$ & $\mathrm{~F}$ & 46 & - & Signet-ring cell carcinoma & Nodule \\
\hline Kwak et $\mathrm{al}^{3}$ & $\mathrm{~F}$ & 41 & 3 & Signet-ring cell carcinoma & Inflammatory**** \\
\hline Kwak et al ${ }^{3}$ & $\mathrm{~F}$ & 23 & - & Signet-ring cell carcinoma & Inflammatory**** \\
\hline Madan et $\mathrm{al}^{30}$ & $\mathrm{~F}$ & 39 & 5 & Signet-ring cell carcinoma & Nodule \\
\hline Di Cosimo et $\mathrm{al}^{31}$ & $\mathrm{~F}$ & 39 & - & Signet-ring cell carcinoma & Nodules \\
\hline Boutis et $\mathrm{a}^{32}$ & $\mathrm{~F}$ & 37 & 3 & Signet-ring cell carcinoma & Inflammatory**** \\
\hline Qureshi et $\mathrm{al}^{33}$ & $\mathrm{~F}$ & 34 & 4 & Signet-ring cell carcinoma & Nodule \\
\hline Isobe et $\mathrm{a}^{34}$ & $\mathrm{~F}$ & 48 & 4 & Signet-ring cell carcinoma & Nodule \\
\hline Hasegawa et al ${ }^{35}$ & $\mathrm{~F}$ & 61 & 3 & Signet-ring cell carcinoma & Nodule \\
\hline Makni et $\mathrm{al}^{36}$ & $\mathrm{~F}$ & 40 & - & Signet-ring cell carcinoma & Nodule \\
\hline Gugić et $\mathrm{al}^{37}$ & $\mathrm{~F}$ & 43 & - & Signet-ring cell carcinoma & Nodule \\
\hline Sato et $\mathrm{al}^{38}$ & $\mathrm{~F}$ & 67 & 4 & Signet-ring cell carcinoma & Inflammatory***** \\
\hline Cil et $\mathrm{al}^{2}$ & $\mathrm{~F}$ & 63 & - & Signet-ring cell carcinoma & Inflammatory***** \\
\hline Cil et $\mathrm{al}^{2}$ & $\mathrm{~F}$ & 65 & - & Signet-ring cell carcinoma & Inflammatory***** \\
\hline lesato et $\mathrm{al}^{\$}$ & $\mathrm{~F}$ & 41 & 4 & Signet-ring cell carcinoma & Inflammatory \\
\hline lesato et $\mathrm{al}^{\$}$ & $\mathrm{~F}$ & 34 & 3 & Signet-ring cell carcinoma & Nodule \\
\hline
\end{tabular}

found simultaneously with the primary site tumors or within one year. This finding suggests that the progression of gastric carcinoma with breast metastasis is rapid and that the possibility of metastasis from gastric carcinoma cannot be denied even if there is no history of gastric cancer. Hamby et al reported a case of breast metastasis from gastric cancer ${ }^{23}$ in which the patient was misdiagnosed as having inflammatory breast cancer and underwent treatments for breast cancer, including chemotherapy, radiation, and total mastectomy of the left breast. 


\begin{tabular}{|c|c|c|c|c|c|}
\hline $\begin{array}{l}\text { Localization of } \\
\text { breast metastasis }\end{array}$ & MMG & US & Other metastatic sites & $\begin{array}{l}\text { Time to breast } \\
\text { metastasis }\end{array}$ & Prognosis \\
\hline Bilateral & - & - & - & - & - \\
\hline Right & - & - & Skin & & - \\
\hline Left & - & - & Liver, pancreas & - & - \\
\hline Bilateral & - & - & - & - & - \\
\hline Bilateral & - & - & Ovaries & - & - \\
\hline- & - & - & - & - & - \\
\hline Left & - & - & - & - & - \\
\hline Bilateral & - & - & - & 4 months & 6 months, died \\
\hline Left & - & - & - & - & - \\
\hline Left & - & - & $\begin{array}{l}\text { Ovaries, axillary nodes, regional } \\
\text { lymph nodes }\end{array}$ & 22 months & 2 months, died \\
\hline- & - & - & - & Concomitant & - \\
\hline- & - & - & - & - & - \\
\hline Left & - & - & - & - & - \\
\hline Left & - & - & - & 1.5 months $* * * * *$ & 3 months, died \\
\hline Left & - & - & - & - & 3 days, died \\
\hline Left & - & - & - & - & - \\
\hline Bilateral & Nodules & Nodules & Axillary lymph nodes & 31 months & 7 months, died \\
\hline Left & - & - & - & Concomitant & I 2 days, died \\
\hline Bilateral & None & - & Lymph nodes & Concomitant & 18 months, alive \\
\hline Right & - & - & Lymph nodes, ovaries & Concomitant & 2 months, died \\
\hline Left & - & - & - & 72 months & 3 months, died \\
\hline Left & - & - & - & 10 months & 3 weeks, died \\
\hline Left & - & - & Left supraclavicular & - & - \\
\hline Left & - & - & Pleura & - & - \\
\hline Bilateral & - & Skin thickening & $\begin{array}{l}\text { Bilateral axillary nodes, mesenteric } \\
\text { and retroperitoneal lymph nodes }\end{array}$ & 2 months & Alive \\
\hline Left & Nodule & Nodule & Bone, axillary lymph nodes & 32 months & 6 months, died \\
\hline Left & Skin thickening & Skin thickening & Ovaries & Concomitant & Alive \\
\hline Right & Skin thickening & Skin thickening & Axillary nodes & Concomitant & Alive \\
\hline Right & - & - & Ovaries, peritoneum & 3 months & Alive \\
\hline Bilateral & - & Nodules & Ovaries, peritoneum, skin & I month & Alive \\
\hline Left & Skin thickening & - & Ovaries, ascites & Concomitant & 6 months, died \\
\hline Left & None & None & None & Concomitant & 6 months, died \\
\hline Right & None & Hypoechoic region & $\begin{array}{l}\text { Axillary, hilar, retropharyngeal } \\
\text { lymph nodes, bone }\end{array}$ & Concomitant & I month, died \\
\hline Right & - & - & $\begin{array}{l}\text { Peritoneal metastases, } \\
\text { regional lymph nodes }\end{array}$ & 50 months & 2 months, died \\
\hline Right & - & Nodule & Ovaries & 4 months & 18 months, died \\
\hline Right & - & - & Lymph nodes & 60 months & 22 months, died \\
\hline Left & Skin thickening & None & Axillary and supraclavicular nodes & 5 months & 4 months, died \\
\hline Left & - & - & None & 12 months & 4 months, died \\
\hline Left & - & - & Right ovary, ascites & 24 months & 6 months, died \\
\hline Bilateral & None & Hypoechoic region & Ovaries, axillary nodes & Concomitant & 9 months, died \\
\hline Left & None & Nodule & Cervix & Concomitant & I 3 months, alive \\
\hline
\end{tabular}

The overall prognosis of patients with breast metastasis of gastric carcinoma is generally poor, with a $>80 \%$ chance of dying within one year, ${ }^{12}$ and only one case involving mucinous differentiation of adenocarcinoma surviving for more than one year. ${ }^{22}$ Our second patient showed a favorable response to systemic chemotherapy, and significant reduction in the size of the primary tumor and metastatic lesions was obtained within 5 months. She continues with chemotherapy. With progress in systemic chemotherapies for gastric cancer, appropriate treatments might improve the prognosis of patients with breast 
metastasis as well as their quality of lives. ${ }^{3}$ Therefore, to apply appropriate treatments to the patient with breast tumor without delay, it is important to distinguish the metastatic cancer from the primary breast cancer. Careful attention is required, especially when a breast lesion is the first manifestation of an unknown primary malignancy.

A definitive diagnosis of breast metastasis is made on the basis of the histologic similarities between the primary and breast lesions. The presence of a periductal and/or perilobular distribution of malignant cells in the absence of an in situ lesion indicates that the metastasis is from another site. ${ }^{38}$ Recently, immunohistochemical analysis has had an important role in identification of primary sites. In our present cases, specific markers for stomach (HIK1083 and MUC5AC), ${ }^{29,43}$ were used in case 1, and specific markers for breast (estrogen/progesterone receptors and GCDFP15) 2,3,30,44 as well as those for stomach (HIK1083 and MUC6) ${ }^{29,43}$ were used in case 2. To identify metastasis of gastric carcinoma, carcinoembryonic antigen and cytokeratins 7 and 20 are frequently used. ${ }^{2,32,33}$ Invasive breast lobular carcinoma shows signet-ring cell differentiation that resembles the signet-ring cell carcinoma of the stomach. GCDFP15, which is positive for breast cancer especially with apocrine features or signet-ring cell differentiation, but negative for breast metastasis of gastric cancer, is helpful in the differential diagnosis., ${ }^{3,30}$

Staining of members of the MUC family is of limited value but is widely used in the differential diagnosis. ${ }^{38}$ In our cases, we also used the HIK1083 antibody. Because HIK 1083 exhibited highly selective reactivity with class III mucins in the gastrointestinal tract, it is considered to be more specific than MUC6. ${ }^{29,43}$ The estrogen receptor is often present in breast cancers, but $>20 \%$ of primary gastric cancers also express the estrogen receptor. ${ }^{2}$ Our cases together with those in previous reports suggest that HIK1083, GCDFP15, and MUC5AC might be a reasonable combination for use in immunohistochemical analysis in the differential diagnosis of malignant tumors of the breast.

\section{Conclusion}

When breast tumors show signet-ring cells without in situ lesions, the possibility that gastric cancer is present should be considered. It is important to distinguish metastatic cancer from primary breast cancer so that patients can receive the most appropriate treatments without delay.

\section{Disclosure}

The authors report no conflicts of interest in this work.

\section{References}

1. Lee SK, Kim WW, Kim SH, et al. Characteristics of metastasis in the breast from extramammary malignancies. J Surg Oncol. 2010;101:137-140.

2. Timuçin Ç, Abdullah A, Semir P, Abdurrahman I. Gastric ring cell carcinoma metastasis to the breast: two case reports. Turk $J$ Cancer. 2009;39:62-65.

3. Kwak JY, Kim EK, Oh KK. Radiologic findings of metastatic signet ring cell carcinoma to the breast from stomach. Yonsei Med J. 2000;41:669-672.

4. Reitmann K. Das sekundare Karzinom der Haut bei primaren Karzinom innerer Organe [The secondary carcinoma of skin from primary carcinoma of inner organ]. Arch Dermatol Syph. 1908;90:351. Dutch.

5. Kreibich C. Uber sekundaren Szirrhus der Haut. Med Klin. 1909;5:1436.

6. Mourier F, Marre L. Envahissement du sein, cancer de l'estomac [Invasion to breast, cancer of stomach]. Arch Med Exp Anat Pathol. 1910;22:433. French.

7. Stahr H. Plastische mastitis bei magenkrebs [Plastic mastitis caused by gastric carcinoma]. Z Krebsforsch. 1922;19:231. Dutch.

8. Dawson EK. Metastatic tumour of the breast, with report of a case. J Pathol. 1936;43:53.

9. Abrams HL, Spiro R, Goldstein N. Metastasis in carcinoma. Cancer. 1949;3:74-85

10. Sandison AT. Metastatic tumours in the breast. Br J Surg. 1959;47:54.

11. Nance FC, MacVaugh H 3rd, Fitts WT Jr. Metastatic tumor to the breast simulating bilateral primary inflammatory carcinoma. Am J Surg. 1966;112:932-935.

12. Hadju SI, Urban JA. Cancers metastatic to the breast. Cancer. 1972;29:1691-1696.

13. Schmutzer KJ, Zaki AE, Regan JF. Gastric carcinoma in a 22 -year-old negro woman with metastases to ovaries and breast. J Natl Med Assoc. $1973 ; 65: 426-428$.

14. Silverman EM, Oberman HA. Metastatic neoplasms in the breast. Surg Gynecol Obstet. 1974;138:26-28.

15. Toombs BD, Kalisher L. Metastatic disease to the breast. Clinical pathologic and radiographic features. Am J Roentgenol. 1977;129:673.

16. Satake T, Esaki M. A metastatic case to the breast of stomach cancer. Gan To Kagaku Ryoho. 1980;26:577-580.

17. Togo S, Kasumi F. A case of gastric cancer metastatic to the breast. Gan No Rinsho. 1980;26:386-393.

18. Nielsen M, Andersen JA, Henriksen FW, et al. Metastases to the breast from extramammary carcinomas. Acta Pathol Microbiol Immunol Scand. 1981;89:251-255.

19. Champault G, Ascher E, Guterman R, et al. Cancer of the breast and gastric linitis. Metastasis or coincidence? Ann Chir. 1982;36:246-248.

20. Kasuga Y, Senga O, Hanamura N, et al. A case of bilateral metastatic breast carcinoma from gastric carcinoma (Jpn). Gan No Rinsho. 1986;32:407-412.

21. Tachibana S, Asano M, Miya K, Hino T, Furuichi N, Misawa K. A case report of gastric cancer with breast metastasis (Jpn). J Clin Surg. 1986;41:1719-1722.

22. Alexander HR, Turnbull AD, Rosen PP. Isolated breast metastases from gastrointestinal carcinomas: report of two cases. J Surg Oncol. 1989;42:264-266.

23. Hamby LS, McGrath PC, Cibull ML, Schwarts RW. Gastric carcinoma metastic to the breast. J Surg Oncol. 1991;48:117-121.

24. Mishina Y, Ohtsuka K, Yamamura H, et al. A case or metastasis of gastric cancer to the mammary gland (Jpn). J Jpn Surg Assoc. 1993;54: 112-117.

25. Cavazzini G, Colpani F, Cantore M, et al. Breast metastasis from gastric signet ring cell carcinoma, mimicking inflammatory carcinoma. A case report. Tumori. 1993;79:450-453.

26. Domanski HA. Metastases to the breast from extramammary neoplasms. A report of six cases with diagnosis by fine needle aspiration cytology. Acta Cytol. 1996;40:1293-300. 
27. De la Cruz Mera A, Marino Cotelo A. Breast metastases. Acta Cytol. 1998;42:1304-1306.

28. Briest S, HornLC, Haupt R, Schneider JP, Schneider U, Hockel M. Metastasizing signet ring cell carcinoma of the stomach, mimicking bilateral inflammatory breast cancer. Gynecol Oncol. 1999;74:491-494.

29. Kudo H, Sakatani T, Shibata S, Ishiguro M, Nishidoi H, Murakami S. A case of gastric cancer metastasized to the breasts (Jpn). J Jpn Surg Assoc. 1999;60:1486-1489.

30. Madan AK, Ternovits C, Huber SA, Pei LA, Jaffe BM. Gastrointestinal metastasis to the breast. Surgery. 2002;132:889-893.

31. Di Cosimo S, Ferreti G, Fazio N, et al. Breast and ovarian metastatic localization of signet-ring cell gastric carcinoma. Ann Oncol. 2003;14:803-804.

32. Boutis AL, Andreadis C, Patakiouta F, Mouratidou D. Gastric signet-ring adenocarcinoma presenting with breast metastasis. World J Gastroenterol. 2006;12:2958-2961.

33. Qureshi SS, Shrikhande SV, Tanuja S, et al. Breast metastases of gastric signet ring cell carcinoma: a differential diagnosis with primary breast signet ring cell carcinoma. J Postgrad Med. 2005;51:125-127.

34. Isobe T, Tokoyama G, Fujii T, Kawamura D, Nakagawa S, Shirouzu K. A case of breast metastasis of gastric cancer progressed rapidly (Jpn). J Jpn Surg Assoc. 2006;67:2800-2804.

35. Hasegawa S, Yoshikawa T, Yoshida T, et al. A case of breast metastasis of gastric cancer (Jpn). Jpn J Cancer Chemother. 2007;34:1115-1118.

36. Krichen Makni S, Abbes K, Khanfir A, Frikha M, Sellami Boudawara T Metastatic signet ring cell carcinoma to the breast from stomach (Fre). Cancer Radiother. 2007;11:276-279.
37. Gugić D, Josipa F, Šambić PM, Mrčela M, Romić S. Breast metastases from gastric carcinoma - a case report. Libri Oncol. 2007;35:59-62.

38. Sato T, Muto I, Fushiki M, et al. Metastatic breast cancer from gastric and ovarian cancer, mimicking inflammatory breast cancer: report of two cases. Breast Cancer. 2008;15:315-320.

39. Howlader N, Noone AM, Krapcho M, et al. SEER Cancer Statistics Review, 1975-2011. National Cancer Institute; Bethseda, MD. Available from: http://seer.cancer.gov/csr/1975_2011/. Accessed November 19, 2014.

40. Japanese Breast Cancer Society. Nationwide breast cancer registration survey report. 2010; No. 41. Available from: http://www.jbcs. gr.jp/Member/nenjitouroku/2010kakutei.pdf. Accessed November 19, 2014.

41. Otsuji E, Yamaguchi T, Sawai K, Takahashi T. Characterization of signet ring cell carcinoma of the stomach. J Surg Oncol. 1998;67:216-220.

42. Chang S, Parker SL, Pham T, Buzdar AU, Hursting SD. Inflammatory breast carcinoma incidence and survival: the surveillance, epidemiology, and end results program of the National Cancer Institute, 1975-1992. Cancer. 1998;82:2366-2372.

43. Iijima M, Nakayama J, Nishizawa T, et al. Usefulness of monoclonal antibody HIK 1083 specific for gastric-glycan in differentiating cutaneous metastasis of gastric cancer from primary sweat gland carcinoma. Am J Dermatopathol. 2007;29:452-456.

44. McGuire WL, Horwitz KB, Pearson OH, Segaloff A. Current status of estrogen and progesterone receptors in breast cancer. Cancer. 1977;39:2934-2947.
OncoTargets and Therapy

\section{Publish your work in this journal}

OncoTargets and Therapy is an international, peer-reviewed, open access journal focusing on the pathological basis of all cancers, potential targets for therapy and treatment protocols employed to improve the management of cancer patients. The journal also focuses on the impact of management programs and new therapeutic agents and protocols on

\section{Dovepress}

patient perspectives such as quality of life, adherence and satisfaction. The manuscript management system is completely online and includes a very quick and fair peer-review system, which is all easy to use. Visit http://www.dovepress.com/testimonials.php to read real quotes from published authors. 